\title{
ŘEČ NA ROZLOUČENOU S IVANEM HAVLEM ${ }^{1}$
}

\section{Vážení přátelé náčelníka Centra pro teoretická studia Ivana Havla!}

Bolestná událost, která nás opět jednou zaskočila, se nazývá smrt. Od té doby, co je člověk člověkem, nemůže se před touto událostí schovat. I kdybychom se nikdy s nikým zemřelým neloučili, víme, že jsme smrtelní. I kdybychom si tuto nejtajemnější stránku svého života jakkoli zastírali a pokoušeli se na ni nemyslet, je pořád s námi a zásadním způsobem spoluurčuje všechno naše konání i nekonání. Jak říká Friedrich Hölderlin: „Život je smrt, a i smrt je přec život.“2

Mnohokrát jsme se s Ivanem v našem transdisciplinárním centru nad tímto tajemstvím všech tajemství zamýšleli - at' už vážně, inspirováni filosofickými úvahami velkých filosofů, nebo - jak už bylo naším dobrým zvykem - v žertu. Když jsem mu přispěl do gratulovníku $\mathrm{k}$ šedesátinám úvahou o čase, $v$ jejímž závěru nemohlo samozřejmě téma smrti chybět, ${ }^{3}$ odpověděl mi jako jednomu ze sto deseti gratulantů takto:

„Gratulant Ivan Chvatík mi opět, zde pod benigním názvem Čas př́tomnos$t i$, připomíná, že umřu. Dobře dělá, chovám se totiž, jako bych měl být nesmrtelný: jen za deset měsíců tohoto roku přibylo do mé knihovny dalších 217 nepřečtených knih... Je to gratulantovo nesmrtelné téma: smrt. O své bytí se staráme ve ,smrtelné vážnosti ', což nám zajišt'uje ,jistotu o spolehlivosti pravdy a skutečnosti, ‘ píše na straně 289. ,A právě proto, aby naše jednání a náš život vůbec tuto skutečnost a opravdovost neztratily, nemůžeme být nesmrtelní. - ,Aby naše jednání a náš život ony bohulibé věci neztratily, říkám si, přece stačí mít jen iluzi, že jsme smrtelní. Možná, že je to jen čistě teoretická ,možnost nebýt, co nám umožňuje být ‘ <289>. Provazolezec nemusí vědět, že kdosi pod něj umístil záchrannou sít' - ba nesmí to vědět, nemá-li přijít o svůj obdiv k vlastní velikosti a o radost z potlesku publika. - ,Skutky neskutky, proč bychom nemohli být velcí díky klamné iluzi? Co když - podobně jako nás naše smysly šetří od nekonečné záplavy zbytečných podrobností - jsme též ušetřeni strašlivé jistoty - že jsme nesmrtelní? ““4

Ano, Ivan Miloš Havel, náš náčelník, je nesmrtelný.

Ivan Chvatik

1 Řeč pronesená na pohřbu Ivana M. Havla 10. května 2021.

2 F. Hölderlin, V rozmilé modři, přel. I. Chvatík, in: I. Chvatík et al., Krupobití. Gratulovník k 70. narozeninám Daniela Kroupy, Ústí nad Labem 2019, str. 24.

3 J. Fiala - I. Chvatík (vyd.), Transdisciplinární gratulovník Ivanu M. Havlovi $k$ šedesátým narozeninám, Praha 2000, str. 285-292.

4 Tamt., str. 611-612. 